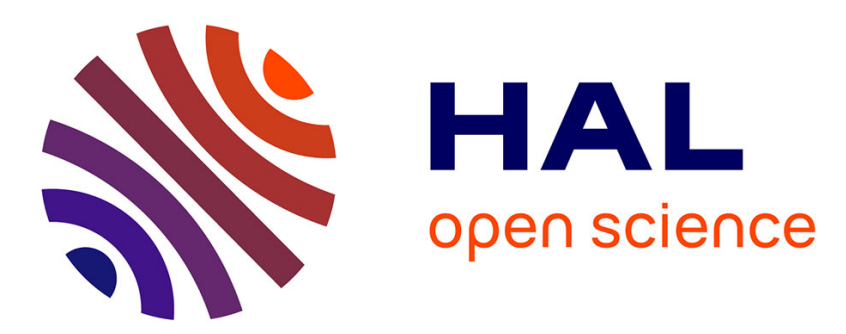

\title{
Lifetimes by Doppler shift using solid and gaseous stopping media
}

\author{
R.W. Kavanagh, N. Schulz, J.C. Merdinger
}

\section{To cite this version:}

R.W. Kavanagh, N. Schulz, J.C. Merdinger. Lifetimes by Doppler shift using solid and gaseous stopping media. Revue de Physique Appliquée, 1969, 4 (2), pp.215-216. 10.1051/rphysap:0196900402021500 . jpa-00243226

\section{HAL Id: jpa-00243226 https://hal.science/jpa-00243226}

Submitted on 1 Jan 1969

HAL is a multi-disciplinary open access archive for the deposit and dissemination of scientific research documents, whether they are published or not. The documents may come from teaching and research institutions in France or abroad, or from public or private research centers.
L'archive ouverte pluridisciplinaire HAL, est destinée au dépôt et à la diffusion de documents scientifiques de niveau recherche, publiés ou non, émanant des établissements d'enseignement et de recherche français ou étrangers, des laboratoires publics ou privés. 


\title{
LIFETIMES BY DOPPLER SHIFT USING SOLID AND GASEOUS STOPPING MEDIA
}

\author{
R. W. KAVANAGH, N. SGHULZ and J. C. MERDINGER, \\ Institut de Recherches Nucléaires, Strasbourg-Cronenbourg.
}

\begin{abstract}
Résumé. - Des valeurs ou limites de la vie moyenne d'états excités dans ${ }^{33} \mathrm{~S},{ }^{38} \mathrm{Ar},{ }^{40} \mathrm{~K}$ et ${ }^{43} \mathrm{Ca}$ ont été obtenues par l'observation des déplacements en énergie des rayonnements $\gamma$ par l'effet Doppler. Des milieux ralentisseurs solides $(\mathrm{Au}, \mathrm{Cu}, \mathrm{C})$ et gazeux (Xe, $\mathrm{Ar}$ ) à différentes pressions $\left(P \leqslant 30 \mathrm{~kg} / \mathrm{cm}^{2}\right)$ ont été utilisés.
\end{abstract}

Abstract. - Lifetime values or limits for low-lying levels in ${ }^{33} \mathrm{~S},{ }^{38} \mathrm{Ar}$ and ${ }^{40} \mathrm{~K}$ have been found from $\gamma$-ray Doppler shift attenuation (DSA) in $\mathrm{Au}, \mathrm{Cu}$, and $\mathrm{C}$ solids, and for levels in ${ }^{33} \mathrm{~S}$ and ${ }^{43} \mathrm{Ca}$ by DSA in Xe and Ar gases at various pressures up to $30 \mathrm{~kg} / \mathrm{cm}^{2}$.

I. Introduction. - Since the advent of high resolution $\mathrm{Ge}(\mathrm{Li})$ detectors, Doppler shift attenuation measurements to obtain lifetimes of nuclear levels have become readily accéssible and widely used. In this method, the nuclear lifetimes have to be compared to the slowing down time of the recoiling excited nuclei. When the ions are stopped in solids, lifetimes in the $10^{-14}$ to $10^{-12}$ second range are observable. By using gaseous media to stop the excited nuclei and varying the gas pressure, the slowing down times can be varied so that lifetimes in the $10^{-12}$ to $10^{-8}$ second range can be measured. Using both of these methods we have determined lifetime values or limits for low-lying levels in ${ }^{33} \mathrm{~S},{ }^{38} \mathrm{Ar},{ }^{40} \mathrm{~K}$ and ${ }^{43} \mathrm{Ca}$.

II. Experimental procedure. - The levels in the nuclei ${ }^{33} \mathrm{~S},{ }^{40} \mathrm{~K}$ and ${ }^{43} \mathrm{Ca}$ were populated by means of $(\alpha, n)$ reactions, and those of ${ }^{38} \mathrm{Ar}$ by the $(\alpha, p)$. The $\alpha$ energies were chosen not too far from thresholds in order to have the nuclei recoil in the forward direction with little spread in angle and initial velocity. Neutron producing reactions generally give good yield even close to threshold. Recoil velocities obtained by bombarding with $\alpha$ particles were in the range $0.004 \leqslant \frac{v}{c} \leqslant 0.008$.

For the measurements with solid stopping media the targets consist of thin evaporated films (typically $20 \mu \mathrm{g} / \mathrm{cm}^{2}$ ) on thick gold, copper and carbon backings. The measurements in ${ }^{43} \mathrm{Ca}$ were performed by use of argon as a common target and stopping gas. For the other measurements with gas stopping media, thin targets were deposited on the gas side of the pressureretaining platinum or Havar foils.

A $22 \mathrm{~cm}^{3}$ coaxial $\mathrm{Ge}(\mathrm{Li})$ counter was placed at distances between 2 and $4 \mathrm{~cm}$ from the target. The detector has a resolution of $3.5 \mathrm{keV}$ for $1.33 \mathrm{MeV}$ $\gamma$-rays. Pulses were amplified by a model 118 A Ortec preamplifier and a model TC 200 Tennelec amplifier. The $\gamma$-ray spectra were recorded in 2048 channels of an Intertechnique pulse-height analyzer. Radioactive sources were used / to calibrate the system in energy and to monitor its stability.

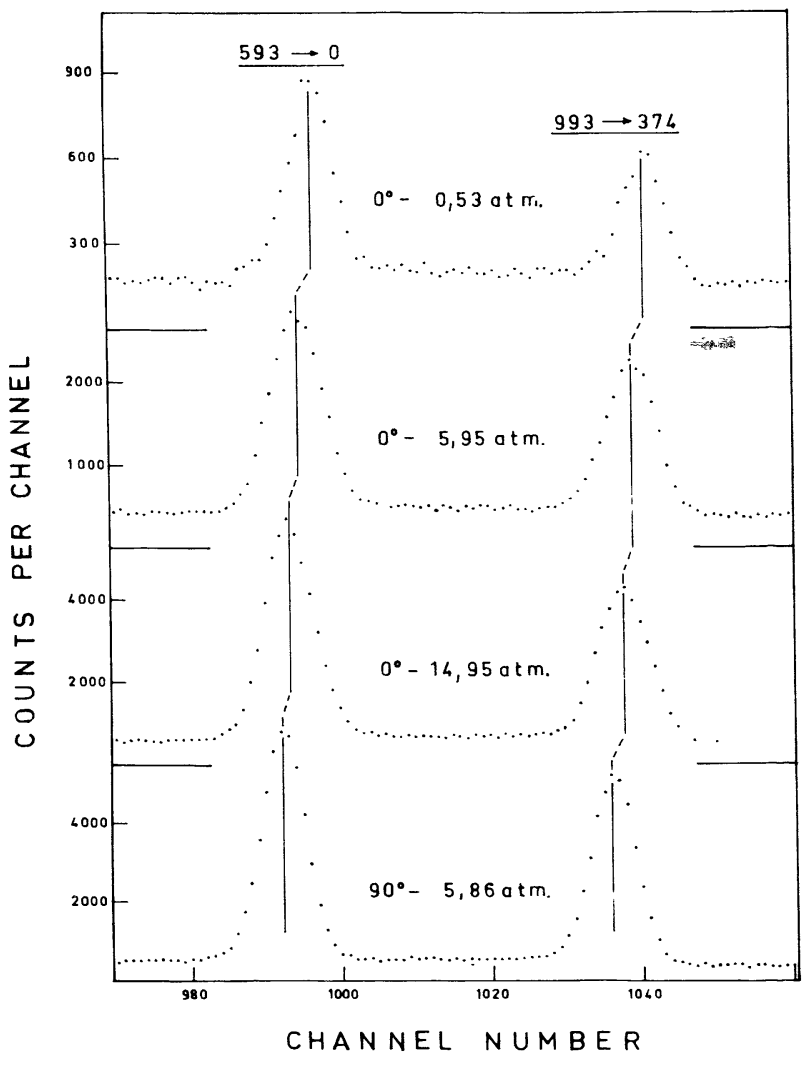

FIG. 1. - Gamma rays from the $593 \rightarrow 0 \mathrm{keV}$ and the $993 \rightarrow 374 \mathrm{keV}$ transitions observed in the ${ }^{4} \mathrm{Ar}(\alpha, \mathrm{n})^{43} \mathrm{Ca}$ reaction for different gas pressures. 
For each level the unshifted $\gamma$-ray energy at $90^{\circ}$ with respect to the incoming beam and the shifted $\gamma$-ray energy at $0^{\circ}$ were measured. For the measurements with gaseous stopping media, the energy of the $\gamma$-rays emitted in the recoil direction was measured at different pressures up to $30 \mathrm{~kg} / \mathrm{cm}^{2}$. Measurements with recoils into vacuum or low pressure were performed in order to obtain the fully shifted $\gamma$-ray energies. These were always found to be in good agreement with the calculated energies. An illustrative example of the results obtained for two gamma-rays in the ${ }^{40} \mathrm{Ar}(\alpha, n){ }^{43} \mathrm{Ca}$ experiment is given in the figure 1.

III. Analysis of the data. - The measured Doppler shift $F$, as a fraction of the full shift, was used to derive the nuclear lifetimes. The centroids of the peaks define the energies of the gamma-rays. The $F(\tau)$ curves were obtained from the theoretical formalism given by Blaugrund [1]. It takes into account the electronic and nuclear contributions to the slowing down and the nuclear scattering of the recoil ions. The electronic contribution is corrected by including the periodic variations of the experimental electronic stopping cross-sections with the atomic number of the recoil ion. Also an adjustable parameter $f_{\mathrm{n}}$ for the nuclear contribution is introduced. For the ions considered here, no experimental range-energy data are available from which one could deduce the correct value of $f_{n}$. However, this latter can also be found when states with well known lifetimes are present, and has been tentatively taken to be about 0.3 of the Fermi-Thomas value [2].

\section{REFERENCES}

[1] Blaugrund (A. E.), Nucl. Phys., 1966, 88, 501.

[2] LindhaRd (J.), ScharfF (M.) and SchioT'T (H. E.), Kgl. Danske Vidensk. Selskab., Mat. Fys. Medd., 1963, 33, 14. 